\title{
PENGARUH PENERAPAN STANDAR PELAYANAN KEFARMASIAN DI PUSKESMAS TERHAD AP PENINGKATAN KEPUASAN PASIEN
}

\author{
Nelly Murni ${ }^{1^{*}}$, Asriwati ${ }^{2}$, Nur'aini $^{3}$ \\ 1,2,3 IImu Kesehatan Masyarakat, Institut Kesehatan Helvetia \\ *Email: nellymurni@rocket.com
}

\begin{abstract}
ABSTRAK
Mutu pelayanan kesehatan yang berhubungan dengan kepuasan pasien dapat memengaruhi derajat kesehatan dan kesejahteraan masyaraka, karena pasien yang merasa puas akan mematuhi pengobatan dan mau datang berobat kembali. Tujuanpenelitian ini untuk mengetahuipengaruh penerapan standard pelayanan kefarmasian di puskesmas terhadap peningkatan kepuasan pasien di Puskesmas Belawan Kota Medan.Penelitian ini menggunakan jenis penelitian kuantitatif dengan rancangan surveianalitik dengan rancangan cross sectional study.Lokasi penelitian ini dilakukan di Puskesmas Belawan Kota Medan. Populasi penelitian yaitu seluruh pasien rawat jalan yang berkunjung ke Puskesmas belawan Kota Medan periode tahun 2019.Adapun jumlah sampel dalam penelitian ini sebanyak 93 orang diperoleh dengan teknikpurposive sampling.Data hasil survey dianalisis dengan menggunakan uji chi-square dan regeresi logistik. Hasil penelitian menunjukkan bahwa ada Ada pengaruh pengkajian resep terhadap peningkatan kepuasan pasien, ada pengaruh Pelayanan Informasi Obat terhadap peningkatan kepuasan pasien, ada pengaruh konseling terhadap peningkatan kepuasan pasien, ada pengaruh Monitoring Efek Samping Obat di rumah terhadap peningkatan kepuasan pasien di Puskesmas Belawan Kota Medan, ada pengaruh pemantauan terapi obat terhadap peningkatan kepuasan pasien, ada pengaruh Evaluasi Penggunaan obat terhadap peningkatan kepuasan pasien, adapun variabel yang paling berpengaruh terhadap peningkatan kepuasan pasien di Puskesmas Belawan Kota Medan adalah variabel pelayanan informasi obat.Berdasarkan hasil penelitian diketahui bahwa pengkajian resep, Pelayanan Informasi Obat, konseling, Monitoring Efek Samping Obat, pemantauan terapi obat, Evaluasi Penggunaan obat berpengaruh terhadap peningkatan kepuasan pasien di Puskesmas Belawan Kota Medan. Adapun saran bagi penelitian ini yaitu diharapkan hasil penelitian ini diharapkan meningkatkan penerapan standard pelayanan kefarmasian sehingga kepuasan pasien meningkat.
\end{abstract}

Kata Kunci: Pelayanan, puskesmas, kefarmasian, kepuasan pasien

\begin{abstract}
The quality of health services related to patient satisfaction can affect the degree of health and well-being of the community. The purpose of this study is to identify if there is an influence on the application of pharmaceutical service standards at the puskesmas to increase patient satisfaction at the Belawan Puskesmas Medan. This research uses quantitative research with analytic survey design with cross sectional study design. The location of this research was conducted at Belawan Health Center, Medan City. The study population was all outpatients visiting the Center in 2019. The number of samples in this study were 93 people by purposive sampling. Survey data were analyzed using the chi-square test and logistic regression. The results showed that there was an effect of prescription review, Drug Information Services, counseling, Monitoring Drug Side Effects at home, drug therapy monitoring, and Evaluation of drug use on increasing patient satisfaction, while the most influential variable on increasing patient satisfaction is the drug information service variable. The suggestion for this research is that it is expected that the results of this study will improve the application of pharmaceutical service standards so that patient satisfaction increases.
\end{abstract}

Keywords: Services, health center, pharmaceutical, patient's satisfaction

\section{PENDAHULUAN}

Mutu pelayanan kefarmasian adalah pelayanan kefarmasian yang menunjukkan tingkat kesempurnaan pelayanan dalam menimbulkan kepuasan pasien sesuai dengan tingkat kepuasan rata-rata masyarakat.Pasien atau masyarakat menilai pelayanan yang bermutu sebagai layanan yang dapat memenuhi harapan dan kebutuhan yang dirasakannya.
Mutu pelayanan kesehatan yang berhubungan dengan kepuasan pasien dapat memengaruhi derajat kesehatan dan kesejahteraan masyarakat, karena pasien yang merasa puas akan mematuhi pengobatan dan mau datang berobat kembali. ${ }^{1}$

Berdasarkan data WHO tahun 2018, diketahui bahwa kepuasan pasien dengan layanan farmasi diberbagai negara dengan 
menggunakan Farmasi Encounter Survey (PES) berhadapan langsung dengan responden berturut-turut segera setelah kunjungan mereka ke apotek berantai yang dipilih secara acak ( $\mathrm{n}=$ 10) atau apotek independen $(n=16)$ di Philadelphia County, Pennsylvania. 15-item PES mengumpulkan data demografis dan meminta responden untuk menilai kepuasan mereka dengan waktu yang dibutuhkan untuk resep yang harus diisi, keterampilan teknis dan kesopanan dari petugas farmasi, kenyamanan lokasi farmasi, dan aspek lain dari pengalaman. Berdasarkan hasil tersebut diketahui bahwa, sekitar $63 \%$ masyarakat menyatakan puas dengan pelayanan kefarmasian, sedangkan 37 $\%$ lagi menyatakan tidak puas karena berbagai faktor. ${ }^{2}$

Berdasarkan data Indikator Capaian Kemenkes RI Tahun 2016 diketahui bahwa capaian pelayanan kefarmasian mencapai angka sebesar $45,39 \%$ dengan target sebesar $45 \%$, dimana pada tahun sebelumnya capaian indikatornya adalah $40,01 \%$ dengan target sebesar $40 \%$. Dari data di atas tampak bahwa target indikator Persentase Puskesmas yang melaksanakan Pelayanan Kefarmasian sesuai standar pada tahun 2015 dan 2016 telah tercapai dengan analisa sebagai berikut: 1) Persentase Puskesmas yang melaksanakan pelayanan kefarmasian sesuai standar mengalami kenaikan 5,39\% dari tahun 2015 dengan capaian $100,86 \%$ dan diharapkan tahun 2017 bisa mencapai target $50 \%$;2) Peningkatan realisasi indikator ini pada tahun kedua Renstra 2015 -2019 menunjukkan hal yang positif dandiharapkan dapat mencapai target indikator akhir di tahun 2019 yakni sebesar $60 \%$. $^{3}$

Berdasarkan data indikator Kinerja SKPD Provinsi Sumatera Utara tahun 2013-tahun 2018 yang mengacu pada tujuan dan sasaran RPJPMD, diketahui bahwa jumlah RSU dan Puskesmas yang melaksanakan pelayanan kefarmasian sesuai standar tahun 2014 yaitu sebanyak 12 RSU dan 12 Puskesmas, tahun 2015 yaitu sebanyak 14 RSU dan 12 Puskesmas, tahun 2016 yaitu sebanyak 16 RSU dan 18 Puskesmas, tahun 2017 yaitu sebanyak 18 RSU dan 24 Puskesmas, tahun 2018 yaitu sebanyak 20 RSU dan 30 Puskesmas, dan kondisi kinerja pelayanan yang akhir periode RPJPMD yaitu sebanyak 20 RSU dan 30 Puskesmas. $^{4}$

Adapun standar kefarmasian menurut Peraturan Menteri Kesehatan Republik Indonesia Nomor 74 tahun 2016 meliputi dua hal, yaitu :1) pengelolaan sediaan farmasi dan bahan medis habis pakai, 2) pelayanan farmasi klinis. Pelayanan farmasi klinis meliputi : a) pengkajian resep, b) pelayanan informasi, c) konseling, d) ronde/visite pasien (khusus puskesmas rawat inap), e) Monitoring Efek samping Obat (MESO), f) pemantauan terapi obat, g) evaluasi penggunaan obat. Pelayanan farmasi klinik merupakan bagian dari Pelayanan Kefarmasian yang langsung dan bertanggung jawab kepada pasien berkaitan dengan Sediaan Farmasi, Alat Kesehatan, dan Bahan Medis Habis Pakai dengan maksud mencapai hasil yang pasti untuk meningkatkan kualitas hidup pasien. $^{3}$

Salah satu Puskesmas yang sudah menerapkan standar kefarmasian berdasarkan Peraturan Menteri Kesehatan Republik Indonesia Nomor 74 tahun 2016 adalah Puskesmas Belawan yang merupakan salah unit pelayanan kesehatan masyarakat di Kota Medan, yang memberi pelayanan kesehatan pada pustu dan kelurahan, Puskesmas Belawan memberikan pelayanan berdasarkan tiga kategori diantaranya JKN (BPJS, ASKES, KIS), KBG (kartu berobat gratis atau JAMKESDA kota Medan), E-KTP. ${ }^{5}$

Berdasarkan survey awal yang dilakukan di Puskesmas Belawan, diketahui bahwa jumlah kunjungan pasien pada Puskesmas Belawan per hari kurang lebih mencapai 56 pasien.Dengan demikian rata-rata jumlah resep yang di layani oleh 2 orang Tenaga Teknis Kefarmasian (selanjutnya TTK) dan 1 orang apoteker perbulan adalah 1.400 resep. Oleh karena jumlah pasien yang banyak tiap harinya akan mempengaruhi pelayanan yang diberikan oleh para petugas kefarmasian di apotek kepada pasien. Misalnya beberapa pasien mengeluh karena pengkajian resep tidak sesuai dengan umur, jenis kelamin dan berat badan pasien, kemudian ketidaktepatan indikasi dan dosis obat sehingga pasien mengalami reaksi obat yang tidak diinginkan seperti alergi. $^{5}$

Beberapa orang TTK sering lupa memberikan informasi terkait warna obat, misalnya warna putih untuk Obat dalam/oral; warna biru untuk Obat luar dan suntik, menempelkan label "kocok dahulu" pada sediaan bentuk suspensi atau emulsi. Ketidakpuasan pasien lainnya misalnya pada saat pasien mempertanyakan tentang informasi obat baik lisan maupun tulisan, TTK dan Apoteker memberikan jawaban yang tidak 
memuaskan sehingga pasien mengalami kebingungan dalam mengonsumsi obat. Selain itu, Apoteker jarang sekali bersedia memberikan konseling dengan pasien/keluarga untuk meningkatkan pengetah uan, pemahaman, kesadaran dan kepatuhan sehingga terjadi pe rubahan perilaku dalam penggunaan obat dan menyelesaikan masala $\mathrm{h}$ yang dihadapi pasien.

Berdasarkan paparan di atas, peneliti tertarik untuk melakukan penelitian tentang "Pengaruh Penerapan Standard Pelayanan Kefarmasian di Puskesmas terhadap Peningkatan Kepuasan Pasien di Puskesmas Belawan Kota Medan".

\section{BAHAN DAN METODE}

Penelitian ini menggunakan jenis penelitian kuantitatif dengan rancangan surveianalitik dengan rancangan cross sectional study.Lokasi penelitian ini dilakukan di Puskesmas Belawan Kota Medan.

Populasi penelitian yaitu seluruh pasien rawat jalan yang berkunjung ke Puskesmas belawan Kota Medan periode tahun 2019 dengan rata-rata kunjungan perbulan yaitu 1.400 pasien.Adapun jumlah sampel dalam penelitian ini sebanyak 93 orang. Teknik yang digunakan adalah purposive sampling.Data hasil survey dianalisis dengan menggunakan uji chi-square dan regeresi logistik.

\section{HASIL}

Analisis Data Univariat

Berdasarkan data yang diperoleh dari hasil penelitian dengan 93 responden dapat dilihat dalam tabel distribusi frekuensi sebagai berikut.

Tabel 1.Distribusi Karakteristik Responden Berdasarkan Jenis Kelamin, Umur, Pendidikan, Pekerjaan, Suku, Agama, Frekuensi Kunjungan

\begin{tabular}{lcr}
\hline Jenis Kelamin & N & Persentase \\
\hline Laki-laki & 37 & $39,78 \%$ \\
\hline Perempuan & 56 & $60,22 \%$ \\
\hline Umur & & $19,35 \%$ \\
\hline 26-35 Tahun & 18 & $50,54 \%$ \\
36-45 Tahun & 47 & $30,11 \%$ \\
46-55 Tahun & 28 & $17,20 \%$ \\
\hline Pendidikan & 16 & $33,33 \%$ \\
\hline SMP & 31 & $18,28 \%$ \\
SMA & 17 & $15,05 \%$ \\
D3 & 14 & $16,14 \%$ \\
D4 & 15 & $28,43 \%$ \\
S1 & & $23,66 \%$ \\
\hline Pekerjaan & 19 & $37,63 \%$ \\
\hline Nelayan & 22 & $18,28 \%$ \\
Wiraswasta & 35 & \\
Karyawan swasta & 17 & $42,26 \%$ \\
PNS & & $46,24 \%$ \\
\hline Suku & 30 & $21,50 \%$ \\
\hline Jawa & 43 & $74,19 \%$ \\
Melayu & 20 & $25,81 \%$ \\
Batak & & \\
\hline Agama & 69 & $11,83 \%$ \\
\hline Islam & 24 & $88,17 \%$ \\
\hline Kristen & & $\mathbf{1 0 0}$ \\
\hline Frekuesi Kunjungan & 11 & \\
\hline Sekali & 82 & \\
Lebih dari sekali & 93 & \\
\hline Jumlah & &
\end{tabular}

Berdasarkan tabel 1 di atas menunjukkan diketahui bahwa dari 93 responden, sebagian besar responden berjenis kelamin perempuan yaitu sebanyak $56(60,22 \%)$ responden, , sebagian besar responden berumur 36-45 tahun yaitu sebanyak $47 \quad(50,54 \%)$ responden, Berdasarkan pendidikan diketahui bahwa dari 93 responden, sebagian besar responden berpendidikan SMA yaitu sebanyak 31 (33,33\%) responden. Berdasarkan pekerjaan diketahui 
bahwa dari 93 responden, sebagian besar responden memiliki pekerjaan karyawan swasta yaitu sebanyak 35 (37,63\%). Berdasarkan suku diketahui bahwa dari 93 responden, sebagian besar responden bersuku Melayu yaitu sebanyak 43 (46,24\%). Berdasarkan agama diketahui bahwa dari 93 responden, sebagian besar responden beragama Islam yaitu sebanyak 69
$(74,19 \%)$. Berdasarkan frekuensi kunjungan diketahui bahwa dari 93 responden, sebagian besar responden memiliki frekuensi kunjungan lebih dari sekali yaitu sebanyak82 $(88,17 \%)$.

\section{Analisis Data Bivariat}

Analisis bivariat, didapatkan hasil sebagai berikut :

Tabel 2.Pengaruh Penerapan Standar Pelayanan Kefarmasian Di Puskesmas Terhadap Peningkatan Kepuasan Pasien Di Puskesmas Belawan Kota Medan

\begin{tabular}{|c|c|c|c|c|c|c|c|}
\hline \multirow{3}{*}{ Pengkajian Resep } & \multicolumn{6}{|c|}{ Kepuasan Pasien } & \multirow{3}{*}{ P value } \\
\hline & \multicolumn{2}{|c|}{ Tidak Puas } & \multicolumn{2}{|c|}{ Puas } & \multicolumn{2}{|c|}{ Jumlah } & \\
\hline & $\mathrm{n}$ & $\%$ & $\mathrm{~N}$ & $\%$ & $\mathrm{n}$ & $\%$ & \\
\hline Tidak Lengkap & 48 & 96,00 & 2 & 4,00 & 50 & 100 & \multirow{3}{*}{0,000} \\
\hline Lengkap & 2 & 4,65 & 41 & 95,35 & 43 & 100 & \\
\hline Jumlah & 50 & 53,76 & 43 & 46,24 & 93 & 100 & \\
\hline & \multicolumn{6}{|c|}{ Kepuasan Pasien } & \multirow{2}{*}{ P value } \\
\hline \multirow[t]{2}{*}{ Pelayanan Informasi Obat } & \multicolumn{2}{|c|}{ Tidak Puas } & \multicolumn{2}{|c|}{ Puas } & \multicolumn{2}{|c|}{ Jumlah } & \\
\hline & $\mathrm{n}$ & $\%$ & $\mathrm{~N}$ & $\%$ & $\mathrm{n}$ & $\%$ & \multirow{4}{*}{0,000} \\
\hline Tidak Dilakukan & 46 & 97,87 & 1 & 2,13 & 47 & 100 & \\
\hline Dilakukan & 4 & 8,70 & 42 & 91,30 & 46 & 100 & \\
\hline Jumlah & 50 & 53,76 & 43 & 46,24 & 93 & 100 & \\
\hline & \multicolumn{6}{|c|}{ Kepuasan Pasien } & \multirow{3}{*}{$P$ value } \\
\hline \multirow[t]{2}{*}{ Konseling } & & k Puas & & Jas & & nlah & \\
\hline & $\mathrm{n}$ & $\%$ & $\mathrm{~N}$ & $\%$ & $\mathrm{n}$ & $\%$ & \\
\hline Tidak Dilakukan & 46 & 93,88 & 3 & 6,12 & 49 & 100 & \multirow{3}{*}{0,000} \\
\hline Dilakukan & 4 & 9,09 & 40 & 90,91 & 44 & 100 & \\
\hline Jumlah & 50 & 53,76 & 43 & 46,24 & 93 & 100 & \\
\hline \multirow{3}{*}{$\begin{array}{l}\text { Monitoring } \\
\text { Obat }\end{array}$} & \multicolumn{6}{|c|}{ Kepuasan Pasien } & \multirow{3}{*}{$\mathrm{P}$ value } \\
\hline & \multicolumn{2}{|c|}{ Tidak Puas } & \multicolumn{2}{|c|}{ Puas } & \multicolumn{2}{|c|}{ Jumlah } & \\
\hline & $\mathrm{n}$ & $\%$ & $\mathrm{~N}$ & $\%$ & $\mathrm{n}$ & $\%$ & \\
\hline Tidak Dilakukan & 44 & 86,27 & 7 & 13,73 & 51 & 100 & \multirow{3}{*}{0,000} \\
\hline Dilakukan & 6 & 14,29 & 36 & 85,71 & 42 & 100 & \\
\hline Jumlah & 50 & 53,76 & 43 & 46,24 & 93 & 100 & \\
\hline
\end{tabular}

Berdasarkan tabel 2 diketahui bahwa dari 93 responden yang diteliti, sebagian besar responden mengatakan apoteker melakukan pengkajian tidak lenggkap yaitu sebanyak 50 $(53,76 \%)$ responden. Dari $50 \quad(53,76 \%)$ responden tersebut, ada sebanyak $48(96,00 \%)$ responden mengatakan bahwa apoteker melakukan pengkajian resep secara tidak lengkap dan merasa tidak puas, dan sebanyak $2(4,00 \%)$ responden mengatakan bahwa apoteker melakukan pengkajian resep secara tidak lengkap dan merasa puas. Berdasarkan hasil perhitungan uji statistik diperoleh nilai $p$ significancy yaitu $0,000<0,05$, sehingga dapat disimpulkan bahwa ada pengaruh pengkajian resep terhadap peningkatan kepuasan pasien di Puskesmas Belawan Kota Medan.
Berdasarkan tabel diketahui bahwa dari 93 responden yang diteliti, sebagian besar responden mengatakan apoteker tidak melakukan pelayanan informasi obat yaitu sebanyak 47 (50,54\%) responden. Dari 47 $(50,54 \%)$ responden tersebut, ada sebanyak 46 $(97,87 \%)$ responden mengatakan bahwa apoteker tidak melakukan pelayanan informasi obat dan merasa tidak puas, dan sebanyak 1 $(2,13 \%)$ responden mengatakan bahwa apoteker tidak melakukan pelayanan informasi obat dan merasa puas. Berdasarkan hasil perhitungan uji statistik diperoleh nilai $p$ significancy yaitu $0,000<0,05$, sehingga dapat disimpulkan bahwa ada pengaruh pelayanan informasi obat terhadap peningkatan kepuasan pasien di Puskesmas Belawan Kota Medan. 
Berdasarkan tabel diketahui bahwa dari 93 responden yang diteliti, sebagian besar responden mengatakan apoteker tidak melakukan pelayanan informasi obat yaitu sebanyak 49 (52,69\%) responden. Dari 49 $(52,69 \%)$ responden tersebut, ada sebanyak 46 $(93,88 \%)$ responden mengatakan bahwa apoteker tidak melakukan konseling dan merasa tidak puas, dan sebanyak $3(6,12 \%)$ responden mengatakan bahwa apoteker tidak melakukan pelayanan informasi obat dan merasa puas. Berdasarkan hasil perhitungan uji statistik diperoleh nilai $p$ significancy yaitu $0,000<0,05$, sehingga dapat disimpulkan bahwa ada pengaruh konseling terhadap peningkatan kepuasan pasien di Puskesmas Belawan Kota Medan.

Berdasarkan tabel diketahui bahwa dari 93 responden yang diteliti, sebagian besar responden mengatakan apoteker tidak melakukan monitoring efek samping obat yaitu sebanyak 51 (53,84\%) responden. Dari 51 $(53,84 \%)$ responden tersebut, ada sebanyak 44 $(86,27 \%)$ responden mengatakan bahwa apoteker tidak melakukan monitoring efek samping obat dan merasa tidak puas, dan sebanyak $7(13,73 \%)$ responden mengatakan bahwa apoteker tidak melakukan monitoring efek samping obat dan merasa puas. Berdasarkan hasil perhitungan uji statistik diperoleh nilai $p$ significancy yaitu $0,000<0,05$, sehingga dapat disimpulkan bahwa ada pengaruh monitoring efek samping obat terhadap peningkatan kepuasan pasien di Puskesmas Belawan Kota Medan.

\section{Analisis Multivariat}

Tabel 3. Hasil Tahapan Kedua Analisis Regresi Logistik

\begin{tabular}{lcccc}
\hline Variabel & B & P value & Exp(B)OR & 95\%Cl for Exp(B) \\
\hline Pelayanan informasi obat & 4,499 & 0,000 & 89,926 & $7,705-1049,505$ \\
Konseling & 2,517 & 0,019 & 12,392 & $1,509-101,786$ \\
\hline
\end{tabular}

Berdasarkan table 3 diatas dapat dilihat bahwa analisis regresi logistik menghasilkan satu variabel yang paling dominan berpengaruh terhadap peningkatan kepuasan pasien di Puskesmas Belawan Kota Medan dengan $p$ value $<0,05$, yaitu pelayanan informasi obat dengan signifikan 0,000 ( $p$ value $<0,05), O R=$ $89,926(95 \% \mathrm{Cl}=7,705-1049,505)$ artinya responden yang mengatakan bahwa apoteker tidak melakukan pelayanan informasi obat mempunyai peluang 89,926 kali terhadap ketidakpuasan pasien di Puskesmas Belawan Kota Medan

\section{PEMBAHASAN}

Kesalahan pengobatan yang terjadi dapat menyebabkan kegagalan terapi, bahkan dapat timbul efek obat yang tidak diharapkan seperti terjadinya interaksi obat. Interaksi obat merupakan suatu reaksi antara obat dan senyawa kimia lain yang dapat mempengaruhi kerja obat sehingga dapat menimbulkan efek yang tidak diinginkan. Tindakan nyata yang dapat dilakukan untuk mencegah medication error oleh seorang apoteker ada lah melakukan skrining resep atau pengkajian resep.

Standar yang digunakan dalam penelitian ini berdasarkan Peraturan Menteri Kesehatan No.74 tahun 2016, dimana kegiatan pengkajian resep dimulai dari persyaratan administrasi (nama, umur, jenis kelamin, berat badan dan tinggi badan pasien, nama dan paraf dokter serta tanggal resep), persyaratan farmasetik (nama obat,bentuk dan kekuatan sediaan, jumlah obat dan aturan cara penggunaan) dan persyaratan klinis (ketepatan indikasi, dosis obat, waktupenggunaan obat, duplikasi dan/atau polifarmasi, reaksi obat yang tidak diinginkan (alergi, efek samping obat, manifestasi klinis lain, kontraindikasi dan interaksi obat).

Berdasarkan hasil penelitian ini diketahui bahwa dari 93 responden yang diteliti, sebagian besar responden mengatakan apoteker melakukan pengkajian tidak lenggkap yaitu sebanyak 50 (53,76\%) responden. Dari 50 $(53,76 \%)$ responden tersebut, ada sebanyak 48 $(96,00 \%)$ responden mengatakan bahwa apoteker melakukan pengkajian resep secara tidak lengkap dan merasa tidak puas, dan sebanyak $2(4,00 \%)$ responden mengatakan bahwa apoteker melakukan pengkajian resep secara tidak lengkap dan merasa puas. Berdasarkan hasil perhitungan uji statistik diperoleh nilai $p$ significancy yaitu $0,000<0,05$, sehingga dapat disimpulkan bahwa ada pengaruh pengkajian resep terhadap peningkatan kepuasan pasien di Puskesmas Belawan Kota Medan.

Permasalahandalamperesepanmerupakans alahsatukejadianmedicationerror.Bentukmedicati onerroryangterjadiadalahpadafase prescribing(err orterjadipadapenulisanresep)yaitukesalahanyang 
terjadiselamaprosesperesepanobatataupenulisa nresep.Dampakdarikesalahantersebutsangatber agam,mulaiyangtidakmemberiresikosamasekalihi nggaterjadinyakecacatanbahkankematian.

Beberapacontohpermasalahandalamperese panadalahkuranglengkapnyainformasipasien,pe nulisanyangtidakjelasatautidakterbaca,kesalahan penulisandosis,tidakdicantumkannyaaturanpema kaianobat,tidakmenuliskanrutepemberianobat,da ntidakmencantumkantandatanganatauparafpenu lisresep. Banyak factor yangmempengaruhi permasalahandalamperesepan,sehinggadiperluk ankepatuhandokterdalammelaksanakanaturanaturandalampenulisanresepsesuaiundangundangyang berlaku..

Peneliti berasumsi bahwa, tindakannyatayangdapatdilakukanuntukmencega $\mathrm{h}$ medicationerrorolehseorangfarmasiadalahmela kukanskriningresepataupengkajianresep.Pengka jianresepdilakukandengantujuanuntukmencegaht erjadinyakelalaianpencantumaninformasi,penulis anresepyangburukdanpenulisanresepyangtidakt epat.Apotekerharusmemahamidanmenyadarike mungkinanterjadinyakesalahanpengobatandala mprosespelayanan.

Hal ini terjadi karena seringkali, dokter dianggap merupakan pemegang keputusan terakhir dalam suatu proses terapi. Namun, dalam hal penggunaan obat, apoteker dan petugas penyerah obat lainnya, merupakan petugas terakhir yang menyerahkan obat kepada pasien. Proses penyerahan obat seringkali diabaikan oleh para penyusun kebijakan di bidang kesehatan selama pengembangan proses pemberian pelayanan kesehatan. Proses ini biasanya dianggap kurang penting dibandingkan proses diagnosis, pengadaan, kontrol penyimpanan dan distribusi. Kelalaian ini sangat merugikan karena proses penyerahan obat yang tidak tepat dan tidak terkontrol dapat menimbulkan dampak buruk bagi sistem pemberian pelayanan kesehatan.

Semua proses yang yang telah dilakukan hingga penentuan obat untuk pasien akan menjadi tidak berguna bila proses penyerahan obat tidak dapat menjamin ketepatan pemberian obat yang benar kepada pasien yang benar dalam dosis dan jumlah yang efektif, dengan instruksi yang jelas dan penyimpanan obat dalam kemasan yang menjamin kestabilan obat. Karena petugas penyerah obat merupakan orang terakhir yang berkomunikasi dengan pasien sebelum obat digunakan, maka proses penyerahan obat merupakan tahap yang sangat penting dalam menentukan penggunaan obat yang tepat. Karena itu, proses ini harus dimengerti oleh setiap pelaku proses penyerahan obat.

Dalam proses penyerahan obat, ada delapan langkah penting yang harus dilakukan untuk menjamin terlaksananya penyerahan obat yang benar kepada pasien dari petugas penyerah obat. Setiap langkah membawa tanggungjawab dan atau pertimbangan yang penting untuk dilakukan. Dalam hal ini, diasumsikan bahwa pemberi resep telah melakukan diagnosis yang benar serta memilih obat yang benar dan regimen yang tepat, serta pasien mempunyai akses terhadap apotik. Petugas penyerah obat menerima resep yang benar dari pasien atau pemberi resep (secara tertulis atau lisan) dan melakukan pengkajian resep terhadap antara lain : Originalitas (keaslian) resep, jika diperlukan komunikasi dengan pemberi resep untuk resep yang meragukan dan tidak jelas, petugas penyerah obat membaca resep dengan benar dan memeriksa ketepatan instruksi yang tertulis pada resep, terhadap

Untuk meningkatkan kepatuhan, pemberian obat harus disertai dengan pemberian informasi yang memadai.Komunikasi dengan pasien atau keluarganya seringkali menemui hambatan, sehingga pasien gagal untuk mengikuti petunjuk pengobatan. Berikut ini beberapa kemungkinan penyebab yang telah teridentifikasi: 1) Ada kesenjangan antar pemberi dan penerima informasi, baik dalam penggunaan bahasa, cara penuturan, ataupun cara pendekatan, 2) Waktu untuk memberikan informasi terbatas, 3) Pemberi informasi tidak berhasil menarik perhatian atau keterbukaan pasie/keluarganya, 3) Informasi yang diberikan tidak diartikan secara benar, atau tidak dimengerti (petunjuk yang diberikan tidak dipahami, petunjuk yang diberikan tidak disepakati, petunjuk yang diberikan tidak dapat dilaksanakan, petunjuk diberikan secara tidak lengkap, hal-hal yang harus dikerjakan terlupa, pasien tidak suka diajak berdiskusi, pasien/keluarga merasa sudah mengetahui, keyakinan pasien/keluarganya sulit diubah.

Peneliti berasumsi bahwa tidak tersampaikannya informasi secara baik, mutlak menjadi tanggung jawab apoteker atau petugas penyerah obat lainnya, walaupun hambatannya mungkin ada di pihak penerima.Untuk itu, perlu diwaspadai kemungkinan adanya hambatan diatas, agar dapat segera diantisipasi. Petugas penyerah obat melakukan pendokumentasian terhadap langkah yang dilakukan, yaitu: memasukkan detil informasi pada profil 
pengobatan pasien, memasukkan data resep, melengkapi data inventori.

Saat ini, pelayanan kefarmasian telah mengalami pergeseran dari orientasi terhadap produk menjadi orientasi terhadap pasien. Bersamaan dengan hal tersebut, tuntutan masyarakat akan pelayanan kefarmasian yang bermutu, permasalahan terkait penggunaan obat, dan permasalahan terkait farmakososioekonomi semakin meningkat sehingga apoteker berperan penting dalam mengatasi permasalahan tersebut.

Sesuai dengan PerMenKes No. 74 Tahun 2016 tentang Standar Pelayanan Kefarmasian di apotek, salah satu upaya apoteker dalam membantu masyarakat dalam menyelesaikan masalah terkait kesehatan dan pengobatannya serta dalam meningkatkan mutu kehidupan pasien adalah memberikan konseling terkait penggunaan obat yang benar.

Konseling obat adalah suatu proses pemberian informasi segala hal terkait obat yang bertujuan membantu pasien dalam mengatasi masalah penggunaan obat, sehingga pengobatan menjadi lebih rasional, aman, efektif dan efisien. Adapun tujuan konseling di Puskesmas Belawan Kota Medan : membantu dalam penyelesaian masalah penggunaan obat agar pengobatan menjadi optimal, aplikasi interaksi profesional apoteker dengan pasien, meningkatkan kualitas pengobatan sehingga kualitas kehidupan pasien menjadi lebih baik, memberi informasi dalam rangka meningkatkan wawasan pasien tentang penggunaan obat dan seluk beluk obat agar pengobatan menjadi lebih optimal, memicu kepedulian/kepekaan pasien akan pentingnya kesehatan dan ketepatan penggunaan obat.

Konseling yang dilakukan di Puskesmas Belawan Kota Medan.memeiliki beberapa tahapan konseling kepada pasien bervariasi sesuai dengan kebijakan dan prosedur sistem kesehatan, lingkungan, dan aturan praktik. Umumnya, langkah-langkah konseling sebagai berikut: membangun rasa percaya dalam membuat hubungan dengan pasien. Perkenalkan diri Anda sebagai seorang apoteker, menjelaskan tujuan dan estimasi waktu dari sesi konseling, dan dapatkan persetujuan pasien untuk berpartisipasi, serta tentukan bahasa lisan utama pasien,

Mengkaji pengetahuan dan sikap pasien tentang penyakit dan obatnya serta kemampuan fisik dan mental untuk menggunakan obat dengan tepat. Tanyakan pertanyaan terbuka tentang tujuan masing-masing obat dan hasil yang diharapkan, dan minta pasien untuk menjelaskan/menunjukkan bagaimana dia akan menggunakan obat, menggunakan demonstrasi untuk mengisi gap antara pengetahuan dan pemahaman pasien. Menunjukkan bentuk, warna, tanda dosis, dll.dari obat yang digunakan serta mendemonstrasikan alat khusus seperti inhaler hidung dan mulut. Sebagai tambahan, sediakan handout tertulis untuk membantu pasien mengingat informasi.Jika seorang pasien mengalami masalah dengan obatnya, kumpulkan data dan kaji masalahnya lalu sesuaikan regimen farmakoterapi sesuai dengan protokol atau memberitahukan dokter pembuat resep, Melakukan verifikasi pengetahuan dan pemahaman pasien tentang penggunaan obatobatan. Minta pasien untuk menjelaskan bagaimana mereka akan menggunakan obat mereka dan mengidentifikasi efeknya. Tempat konseling, Ruang konseling sekurang-kurangnya memiliki satu set meja dan kursi konseling, lemari buku, buku-buku referensi, poster, leaflet, alat bantu konseling, formulir catatan pengobatan pasien dan buku catatan konseling.

Monitoring Efek Samping Obat (MESO) adalah kegiatan pemantauan dan pelaporan efek samping obat yang dilakukan oleh tenaga kesehatan secara sukarela (voluntary reporting) dengan menggunakan formulir pelaporan ESO berwarna kuning, yang dikenal sebagai form kuning.Monitoring dilakukan terhadap seluruh obat yang beredar dan digunakan dalam pelayanan kesehatan di Indonesia.Aktifitas monitoring ESO dan juga pelaporannya yang dilakukan oleh sejawat tenaga kesehatan sebagai healthcare provider merupakan suatu alat yang dapat digunakan untuk mendeteksi kemungkinan terjadinya ESO yang serius dan jarang terjadi.

Tujuan MESO adalah untuk sedini mungkin memperoleh informasi baru mengenai efek samping obat, tingkat kegawatan, frekuensi kejadiannya, sehingga dapat segera dilakukan tindak lanjut yang diperlukan, seperti penarikan obat yang bersangkutan dari peredaran; pembatasan penggunaan obat, misalnya perubahan golongan obat; pembatasan indikasi; perubahan penandaan; dan tindakan lain yang dianggap perlu untuk pengamanan atau penyesuaian penggunaan obat.

Kegiatan pemantauan dan pelaporan MESO yang dilakukan di Puskesmas Belawan bertujuan untuk: menemukan ESO atau ROTD sedini mungkin terutama yang berat, tidak dikenal. dan frekuensinya jarang, menentukan frekuensi dan insidensi ESO atau ROTD yang 
sudah dikenal dan yang baru saja ditemukan, mengenal semua faktor yang mungkin dapat menimbulkan/mempengaruhi angka kejadian dan hebatnya ESO atau ROTD, meminimalkan risiko kejadian ESO atau ROTD, mencegah terulangnya kejadian ESO atau ROTD

Dari hasil wawancara dengan apoteker di Puskesmas Belawan adapun beberapa faktor pemicu efek samping obat antara lain, faktor obat: dosis obat, efek sitotoksik dalam dosis terapi, obat dengan indeks terapi sempit, perubahan formulasi, dan perubahan fisik obat, faktor penderita/pasien: usia, jenis kelamin, genetik, keadaan umum penderita, penyakit yang menyertai/yang diderita, hipersensitivitas, polifarmasi/multiple drug therapy, faktor pemberian: prosedur pemberian obat yang salah dan interaksi obat

Di dalam formulir pelaporan ESO atau formulir kuning, tercantum tabel Algoritma Naranjo, yang dapat sejawat tenaga kesehatan manfaatkan untuk melakukan analisis kausalitas per individu pasien.Analisis ini terdiri atas 10 pertanyaan, apakah ada laporan konvulsif dari reaksi tersebut,apakah kejadian yang tidak diinginkan (adverse event) muncul pada obat yang dicurigai telah diberikan, apakah kejadian yang tidak diinginkan tadi menghilang ketika obat dihentikan atau diberikan antagonis spesifik, apakah reaksi yang tidak diinginkan muncul kembali ketika obat diberikan kembali, apakah ada penyebab alternatif (selain dari obat) dari individu yang menyebabkan reaksi tersebut, apakah reaksi muncul kembali ketika diberi placebo, apakah obat yang terdeteksi dalam darah (atau cairan lain) diketahui bersifat toksik, apakah reaksi bertambah keparahannya ketika dosis ditambahkan atau berkurang keparahannya ketika dosis dikurangi, apakah pasien memiliki reaksi yang sama dengan obat yang sama atau serupa pada apapun paparan sebelumnya, apakah kejadian yang tidak diinginkan telah dikonfirmasi melalui bukti objektif.

Oleh karena itu apoteker wajib melakukan konseling kepada pasien mengenai efek samping obat yang dapat timbul sebelum menyerahkan obat. Hal-hal yang perlu diingatkan kepada pasien, yaitu membaca dosis dan aturan pakai, melihat tanda peringatan, melihat efek samping obat, jangan sembarangan memberikan obat kepada orang lain, selalu memperhatikan tanggal kadaluarsa dan kandungan obat .

\section{KESIMPULAN DAN SARAN}

Berdasarkan hasil penelitian diketahui bahwa pengkajian resep, Pelayanan Informasi Obat, konseling, Monitoring Efek Samping Obat, pemantauan terapi obat, Evaluasi Penggunaan obat berpengaruh terhadap peningkatan kepuasan pasien di Puskesmas Belawan Kota Medan. Adapun saran bagi penelitian ini yaitu diharapkan hasil penelitian ini diharapkan meningkatkan penerapan standard pelayanan kefarmasian sehingga kepuasan pasien meningkat.

\section{REFERENSI}

1. Zeithaml VA, Berry LL, Parasuraman A. The behavioral consequences of service quality. Jurnal Marketing. SAGE Publications Sage CA: Los Angeles, CA; 2006;60(2):31-46.

2. Organiation WH. Farmasi Encounter Survey. Administrative system of the Marathas. University Calcutta. 2018.

3. Menteri Kesehatan Republik Indonesia. Peraturan Menteri Kesehatan Republik Indonesia Nomor 74 Tahun 2016 Tentang Pedoman Manajemen Puskesmas. Kementeri Kesehatan Republik Indonesia Jakarta. 2016.

4. Dinas Kesehatan Provinsi Sumatera UtaUtara. Profil Dinas Kesehatan Provinsi Sumatera Utara. Gerak MasyarakatHidup Sehat. 2018.

5. Badan Pusat Statistik. Profil Puskesmas Belawan dalam Angka. 2018. https://padangsidimpuankota.bps.go.id/Kotl er $\mathrm{P}$, Armstrong $\mathrm{G}$. Principles of marketing. Pearson education; 2010. 